\title{
Length-weight relationships of ornamental fish fromfloodplain lakes in the Solimões River basin (Iranduba, Amazonas, Brazil)
}

Relaciones longitud-peso de peces ornamentales de lagos de llanuras aluviales en la cuenca del río Solimões (Iranduba, Amazonas, Brasil)

Sampaio A, Aguiar-Santos J, Anjos H, Freitas C, Siqueira-Souza F. Length-weight relationships of ornamental fish from floodplain lakes in the Solimões River basin (Iranduba, Amazonas, Brazil). Rev Colombiana Cienc Anim. Recia. 2019; 11(2):Articulo733. DOI: https://doi.org/10.24188/recia. v11.n2.2019.733

Universidad de Sucre, Colombia

Los autores permiten a RECIA reimprimir el material publicado en él. En caso de que un autor quiera traducir o usar una publicación parcial o completa de nuestro Diario, el autor debe obtener un permiso por escrito del editor de la revista.

Revista Colombiana de Ciencia Animal - RECIA está distribuido bajo una Licencia Creative Commons Atribución-CompartirIgual 4.0 Internacional. 


\title{
Length-weight relationships of ornamental fish from floodplain lakes in the Solimões River basin (Iranduba, Amazonas, Brazil)
}

\section{Relaciones longitud-peso de peces ornamentales de lagos de llanuras aluviales en la cuenca del río Solimões (Iranduba, Amazonas, Brasil)}

André Sampaio

DOI: https://doi.org/10.24188/recia.v11.n2.2019.733

Federal University of Amazonas, Laboratory of fisheries ecology,

Manaus, Brazil

andre28sampaio@gmail.com

(i) https://orcid.org/0000-0002-1908-4393

\section{Jamerson Aguiar-Santos}

National Institute for Amazonian Research, Laboratory of Aquatic

Ecosystems, Manaus, Brazil

jamersonaguiar1@gmail.com

(i) https://orcid.org/0000-0003-4666-0226

\section{Hélio Anjos}

Federal University of Amazonas, Postgraduate Program in

Fisheries Science in the Tropics, Manaus, Brazil

heliodosanjos@gmail.com

(D) https://orcid.org/0000-0002-5414-5518

\section{Carlos Freitas}

Federal University of Amazonas, Laboratory of fisheries ecology,

Manaus, Brazil

freitasc50@gmail.com

(i) https://orcid.org/0000-0001-5406-0998

\section{Flávia Siqueira-Souza}

Federal University of Amazonas, Laboratory of fisheries ecology,

Manaus, Brazil

flakel.souza@gmail.com

(i) https://orcid.org/0000-0002-8723-8956

Recepción: 27 Agosto 2019

Aprobación: 25 Noviembre 2019

Publicación: 29 Noviembre 2019

\begin{abstract}
This research reports the LWR of ornamental fish from floodplain lakes of the Solimões River basin. The fish were caught in the Paciência island (a fluvial island) in two lakes Sacambú and Cacau using purse seine $7 \mathrm{~m} \times 4 \mathrm{~m}$ and mesh size = $3 \mathrm{~mm}$, once during the flood in June 2017 and dry in January 2018. The specimens captured were anesthetized using eugenol $15 \mathrm{mg} \cdot \mathrm{L}^{-1}$, fixed formalin $10 \%$ and stored ethanol $70 \%$ after 10 days. This study provides the LWR parameters for the species Anablepsoides micropus, Anchoviella jamesi, Cichlasoma amazonarum, Heros efasciatus, Ctenobrycon hauxwellianus, Copella nattereri and Hemigrammus levis. The parameter a ranged from 0.0092 to $0.0229, b$ ranged from 2.78 to 3.50 and the $R^{2}$ ranged from 0.985 to 0.998 . The results represent new information about ornamental fish from floodplain lakes, with new LWR for five species that are not present in FishBase data set and probably are new for science. This study is preliminary and much work needs to be done especially in the Solimões River floodplain areas and with our research we hope to encourage new studies in the region.
\end{abstract}

Keywords: Amazonia, Amazonian floodplains, Freshwater fish, Ichthyofauna.

Sampaio A, Aguiar-Santos J, Anjos H, Freitas C, Siqueira-Souza F. Length-weight relationships of ornamental fish from floodplain lakes in the Solimões River basin (Iranduba, Amazonas, Brazil). Rev Colombiana Cienc Anim. Recia. 2019; 11(2):Articulo733. D0I: https://doi.org/10.24188/recia.v11. n2.2019.733 


\section{RESUMEN}

Esta investigación informa el LWR de peces ornamentales de lagos de llanuras aluviales de la cuenca del río Solimões. Los peces fueron capturados en la isla de Paciência (una isla fluvial) en dos lagos Sacambú y Cacau utilizando cerco $7 \mathrm{~m} \times 4 \mathrm{~m}$ y tamaño de malla $=3 \mathrm{~mm}$, una vez durante la inundación en junio de 2017 y seco en enero 2018. Las muestras capturadas se anestesiaron con eugenol $15 \mathrm{mg} \cdot \mathrm{L}^{-1}$, se fijaron formalina al $10 \%$ y se almacenaron etanol al $70 \%$ después de 10 días. Este estudio proporciona los parámetros LWR para las especies Anablepsoides micropus, Anchoviella jamesi, Cichlasoma amazonarum, Heros efasciatus, Ctenobrycon hauxwellianus, Copella nattereri y Hemigrammus levis. El parámetro a varió de 0.0092 a $0.0229, b$ varió de 2.78 a 3.50 y el R2 varió de 0.985 a 0.998 . Los resultados representan nueva información sobre peces ornamentales de lagos de llanuras aluviales, con nuevos LWR para cinco especies que no están presentes en el conjunto de datos FishBase y probablemente son nuevos para la ciencia. Este estudio es preliminar y queda mucho trabajo por hacer, especialmente en las áreas de la llanura aluvial del río Solimões y con nuestra investigación esperamos alentar nuevos estudios en la región.

Palabras clave: Amazonia, llanuras aluviales amazónicas, Peces de agua dulce, Ictiofauna.

\section{INTRODUCTION}

The Amazon is the source of many species of ornamental fish, extracted from nature, found in the world aquarium market (1). In addition, has the most diversified ichthyofauna in the world (2) which comprises small-sized species living in lakes, floodplain and small streams (3).

Because of this diversity, studies about length-weight relationships (LWR) of ornamental fish have been more frequent, highlighting the studies by Santos et al (4), Gaspar et al (5), Barros et al (6), Freitas et al (7) and Salvador et al (8). Nevertheless, still there is a lack of information and few studies were conducted in the Solimões River basin about the LWR of ornamental fish species from floodplain lakes.

The studies of LWR have a wide application, despite being easily obtained many data were not published for several species. These data become very relevant, especially in the Amazon, where fishes represent a relevant economic source, either commercial or ornamental (9).

The LWR are important in management and conservation because they are helpful for the evaluation of fish populations when only length measurements exist and enable the computation of condition indexes and the comparison of species growth (between sexes, seasons or regions) (10). In addition, relationships of total, standard and fork lengths of fishes are also important for comparative growth studies (11).

Given the information presented, the objective of the research was to determine the LWR of the ornamental fish from floodplain lakes in the Solimões River.

\section{MATERIALS AND METHODS}

The Paciência island is a fluvial island located in the rural area of the city of Iranduba, in lower Solimões River, far away about $45 \mathrm{~km}$ from the confluence with the Negro River, Amazonas, Brazil (Figure 1).

The samples were obtained in two lakes: Sacambú and Cacau. The fish were caught in mixed floating meadows during the flood in June 2017 and dry in January 2018, once in each season, using purse seine $(7 \mathrm{~m} \times 4 \mathrm{~m}$, mesh size $=3 \mathrm{~mm})$. The definition of the hydrological cycle seasons followed Bittencourt and Amadio (12).

The specimens captured were anesthetized using eugenol $\left(15 \mathrm{mg} \cdot \mathrm{L}^{-1}\right.$ ), fixed (formalin $10 \%$ ) and stored (ethanol 70\%) after 10 days. The Biometry (Standard Length and Total Weight) was realized at the Fishery Ecology Laboratory of the Federal University of Amazonas, using precision balance $(0.001 \mathrm{~g})$ and ichthyometer $(0.1 \mathrm{~cm})$. 


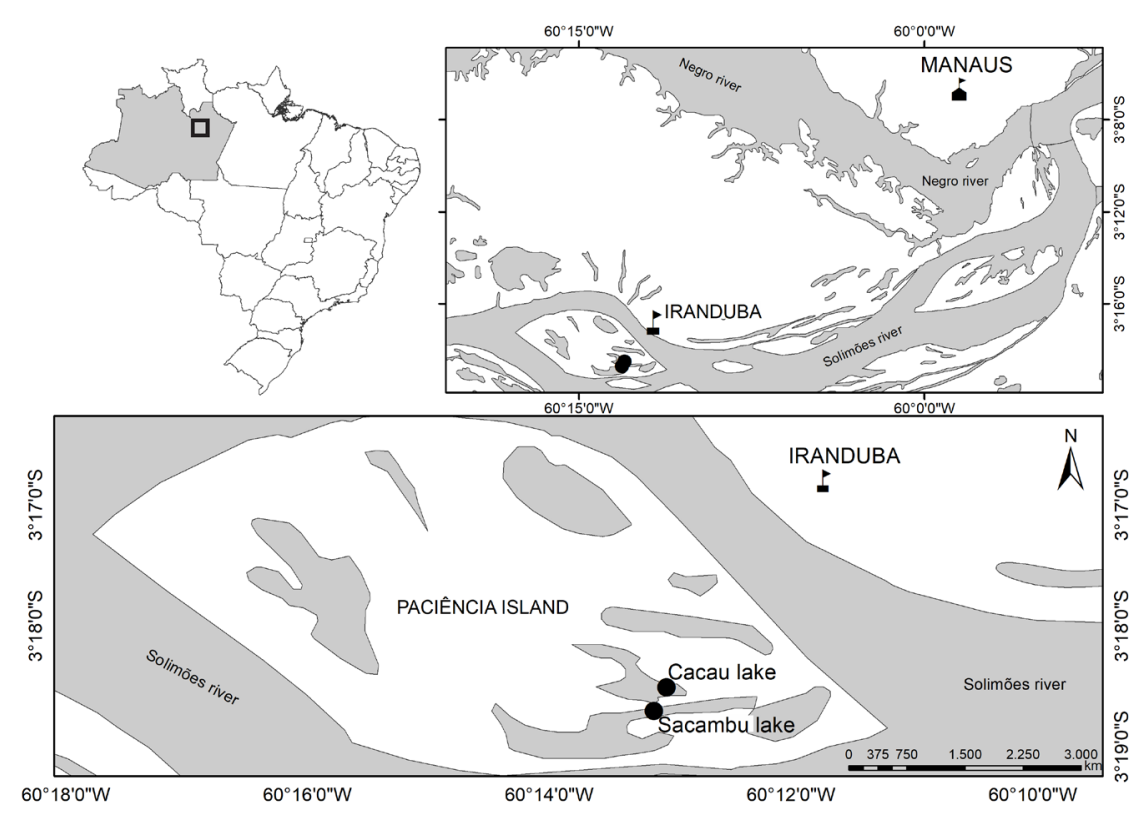

Figure 1. Map of Paciência Island, Iranduba - Amazonas.

The values were determined by non-linear estimation using the algorithm of Levenberg-Marquardt, a technique widely adopted in a broad spectrum of disciplines and that provides solution to problem called Nonlinear Least Squares Minimization (13), in the equation: TW $a \times \mathrm{SL}^{b}$ (14), TW (total weight), SL (standard length), $a$ (intercept) and $b$ (allometric coefficient). Plots of TW and SL were used to exclude outliers (10). After that the values of $a$ and $b$ were compared to know if they were within the confidence limit of Bayesian LWR available on Fishbase. (15). The species was stored in the Fishery Ecology Laboratory/UFAM. The ethics committee on the use of animals of the Federal University of Amazonas (№ 038/2017) approved the study.

\section{RESULTS}

The species examined were Ctenobrycon hauxwellianus and Hemigrammus levis (Characidae), Cichlasoma amazonarum and Heros efasciatus (Cichlidae), Anchoviella jamesi (Engraulidae), Copella nattereri (Lebiasinidae) and Anablepsoides micropus (Rivulidae). The coefficient b varied from 2.78 from Copella nattereri, to 3.50 for C. amazonarum and $H$. efasciatus. Coefficient of determination $\left(R^{2}\right)$ varied from 0.985 C. hauxwellianus, H. levis and A. jamesi, to 0.998 for C. amazonarum. The table 1 summarizes the LWR parameters for all species.

Table 1. Sample size (N), Total weight (TW) and Standard length (SL) ranges, LWR parameters ( $a$ and $b$ ), 95\% confidence Limits (CL) of each parameter and coefficient of determination $\left(\mathrm{R}^{2}\right)$ of the studied species.

\begin{tabular}{|c|c|c|c|c|c|c|c|c|c|}
\hline \multirow{2}{*}{ Family } & \multirow{2}{*}{ Species } & \multirow{2}{*}{$\mathbf{N}$} & \multirow{2}{*}{$\begin{array}{c}\text { TW (g) } \\
\text { (min-max) }\end{array}$} & \multirow{2}{*}{$\begin{array}{c}\text { SL (cm) } \\
\text { (min-max) }\end{array}$} & \multirow{2}{*}{$\mathbf{a}\left(\mathrm{CL}_{95 \%} \mathbf{a}\right)$} & \multirow{2}{*}{ b (CL $\left.{ }_{95 \%} \mathbf{b}\right)$} & \multirow{2}{*}{$\mathbf{R}^{2}$} & \multicolumn{2}{|c|}{ Bayesian length-weight } \\
\hline & & & & & & & & $\mathbf{a}$ & b \\
\hline \multirow[t]{2}{*}{ Characidae } & $\begin{array}{l}\text { Ctenobrycon hauxwellianus } \\
\text { (Cope, 1870) }\end{array}$ & 67 & $0.309-2.76$ & $2.6-5.0$ & $\begin{array}{c}0.0173 \\
(0.0134-0.0213)\end{array}$ & $\begin{array}{c}3.20^{*} \\
(3.04-3.35)\end{array}$ & 0.985 & $\begin{array}{c}0.0120 \\
(0.0063-0.0229)\end{array}$ & $\begin{array}{c}3.02 \\
(2.85-3.19)\end{array}$ \\
\hline & $\begin{array}{l}\text { Hemigrammus levis } \\
\text { Durbin, } 1908\end{array}$ & 28 & $0.022-0.404$ & $1.2-3.2$ & $\begin{array}{c}0.0104 \\
(0.0070-0.0138)\end{array}$ & $\begin{array}{c}3.20 \\
(2.89-3.51)\end{array}$ & 0.985 & $\begin{array}{c}0.0128 \\
(0.0060-0.0275)\end{array}$ & $\begin{array}{c}3.05 \\
(2.87-3.23)\end{array}$ \\
\hline \multirow[t]{2}{*}{ Cichlidae } & $\begin{array}{l}\text { Cichlasoma amazonarum } \\
\text { Kullander, } 1983\end{array}$ & 15 & $0.096-5.37$ & $1.6-4.7$ & $\begin{array}{c}0.0228 \\
(0.0165-0.0292)\end{array}$ & $\begin{array}{c}3.50^{*} \\
(3.32-3.69)\end{array}$ & 0.998 & $\begin{array}{c}0.0195 \\
(0.0086-0.0441)\end{array}$ & $\begin{array}{c}3.07 \\
(2.88-3.26)\end{array}$ \\
\hline & $\begin{array}{l}\text { Heros efasciatus } \\
\text { Heckel, } 1840\end{array}$ & 48 & $0.035-0.498$ & $1.1-2.4$ & $\begin{array}{c}0.0229 \\
(0.0214-0.0243)\end{array}$ & $\begin{array}{c}3.50^{*} \\
(3.42-3.59)\end{array}$ & 0.997 & $\begin{array}{c}0.0316 \\
(0.0143-0.0696)\end{array}$ & $\begin{array}{c}3.00 \\
(2.82-3.18)\end{array}$ \\
\hline Engraulidae & $\begin{array}{c}\text { Anchoviella jamesi } \\
\text { (Jordan \& Seale, 1926) }\end{array}$ & 12 & $1.22-1.58$ & $4.8-5.2$ & $\begin{array}{c}0.0092 \\
(0.0036-0.0148)\end{array}$ & $\begin{array}{c}3.12 \\
(2.74-3.50)\end{array}$ & 0.985 & $\begin{array}{c}0.0052 \\
(0.0024-0.0111)\end{array}$ & $\begin{array}{c}3.13 \\
(2.96-3.30)\end{array}$ \\
\hline Lebiasinidae & $\begin{array}{c}\text { Copella nattereri } \\
\text { (Steindachner, 1876) }\end{array}$ & 11 & $0.114-0.483$ & $2.4-3.8$ & $\begin{array}{c}0.0118 \\
(0.0076-0.0160)\end{array}$ & $\begin{array}{c}2.78^{* *} \\
(2.49-3.07)\end{array}$ & 0.992 & $\begin{array}{c}0.0046 \\
(0.0018-0.0121)\end{array}$ & $\begin{array}{c}3.14 \\
(2.91-3.37)\end{array}$ \\
\hline Rivulidae & $\begin{array}{l}\text { Anablepsoides micropus } \\
\text { (Steindachner, 1863) }\end{array}$ & 17 & $0.021-1.13$ & $1.6-4.4$ & $\begin{array}{c}0.0100 \\
(0.0060-0.0141)\end{array}$ & $\begin{array}{c}3.22 \\
(2.93-3.52)\end{array}$ & 0.992 & $\begin{array}{c}0.0102 \\
(0.0041-0.0252)\end{array}$ & $\begin{array}{c}3.05 \\
(2.83-3.27)\end{array}$ \\
\hline
\end{tabular}

* = Value above of the Bayesian limits. ** = Value below of the Bayesian limits. 


\section{DISCUSSION}

The $b$ values were according with the limits suggested by Froese (2.5 to 3.5) (10). When $b$ values are out of range (2.5 to $3.5)$ it means that, the samples have narrow size ranges and that the mean $b$ values do not show a normal distribution (16).

The species C. hauxwellianus, $C$. amazonarum and H. efasciatus presented values of $b$ above of the confidence limit of Bayesian estimates, and C. nattereri presented value of $b$ below of the confidence limit of Bayesian estimates.

The difference between the values obtained and Bayesian estimates occurs because the values present in FishBase arise from estimates of different species belonging to the same family or genus and with the same body shape (17).

These differences also may be explained by environmental and physiological factors such as seasonality, gonadal maturity, degree of stomach fullness and even the preservation technique and sample size $(18,19)$.

Gaspar et al (5) presented the value of $b=3.003$ for the species $C$. hauxwellianus which is different from our study $b=$ 3.20. The sample size $(\mathrm{N}=67)$ and the length class $(2.6-5.0 \mathrm{~cm})$ may explain the difference between the values, since in our study these values were better distributed.

The species H. levis in our study had $b=3.20$, very similar to the value found by Salvador et al (8) $b=3.179$. One possible explication may be that the length class of the studies present very similar values, our study $(1.2-3.2 \mathrm{~cm})$ and $(1.3-4.0$ $\mathrm{cm})(8)$.

The data used were collected from formalin fixed samples $(20,21)$, this occurred because of the difficulty of the identification of small fishes correctly in the field. Following Barros et al (6), we suggest that this information is very necessary for future research about ornamental fish from floodplain lakes, since there is few information available in the literature.

The results represent new information about ornamental fish from floodplain lakes, with new LWR for five species that are not present in FishBase data set and probably are new for science. This study is preliminary and much work needs to be done especially in the Solimões River floodplain areas and with our research we hope to encourage new studies in the region.

\section{Conflict of interest}

No conflicts by the authors

\section{Acknowledgements}

The authors would like to thank CNPq for financial support, UFAM for the structure of work and all the members from LABEP/UFAM for all help during the study.

\section{REFERENCES}

1. Moreau MA, Coomes OT. Aquarium fish exploitation in western Amazonia: Conservation issues in Peru. Environmental Conservation. 2007; 34(1):12-22. https://doi.org/10.1017/S0376892907003566

2. Albert J, Reis, RE. Historical biogeography of Neotropical freshwater fishes. CA: University of California Press. 2011. https://doi.org/10.1525/california/9780520268685.001.0001

3. Crampton WGR. An ecological perspective on diversity and distributions. In Albert JS, Reis RE. Historical biogeography of Neotropical freshwater fishes (pp. 165-189). CA: University of California Press. 2011. https://doi.org/10.1525/ california/9780520268685.001.0001

4. Santos MQC, Gonzaga Lemos JR, Nascimento Pereira C, Teixeira de Oliveira A, Tavares-Dias M, Marcon JL. Lengthweight relationships of four freshwater ornamental fish species from the Brazilian Negro River basin. Journal of applied ichthyology. 2012; 28(1): 148-149. https://doi.org/10.1111/j.1439-0426.2011.01895.x 
5. Gaspar S, Tobes I, Miranda R, Leunda PM, Peláez M. Length-weight relationships of sixteen freshwater fishes from the Hacha River and its tributaries (Amazon Basin, Caquetá, Colombia). Journal of Applied Ichthyology. 2012; 28(4):667670. https://doi.org/10.1111/j.1439-0426.2011.01928.x

6. Barros TF, Althoff BB, Pereira DC, Lazzarotto H, Caramaschi ÉP. Length-weight relationships in seven ornamental freshwater species of Characiformes from the Unini River basin (Brazilian Amazon). Journal of Applied Ichthyology. 2018; 34(5):1188-1191. https://doi.org/10.1111/jai.13699

7. Freitas TM, De Paula ATT, Leão H, Benone NL, Montag LF. Length-weight relationships of 11 fish species from streams of Anapu River Basin, State of Pará, eastern Amazon, Brazil. Journal of Applied Ichthyology. 2019; 35(3): 793-795. https://doi.org/10.1111/jai.13893

8. Salvador GN, Maia C, Dutra GM, Pessali TC, Benone NL, Montag LF, Freitas TM. Length-weight relationships of eight fish species from Guyana coastal drainages, Amapá, Brazil. Journal of Applied Ichthyology. 2019; 35(4):1039-1041. https://doi.org/10.1111/jai.13917

9. Reis RE, Albert JS, Di Dario F, Mincarone MM, Petry P, Rocha LA. Fish biodiversity and conservation in South America. Journal of Fish Biology. 2016: 89; 12-47. https://doi.org/10.1111/ifb.13016

10. Froese R. Cube law, condition factor and weight-length relationships: history, meta-analysis and recommendations. Journal of Applied Ichthyology. 2006; 22(4):241-253. https://doi.org/10.1111/j.1439-0426.2006.00805.x

11. Moutopoulos DK, Stergiou, KI. Length-weight and length-length relationships of fish species from Aegean Sea (Greece).Journal of Applied Ichthyology.2002; 18(3):200-203.https://doi.org/10.1046/j.1439-0426.2002.00281.x

12. Bittencourt MM, Amadio SA. Proposta para identificação rápida dos períodos hidrológicos em áreas de várzea do rio Solimões-Amazonas nas proximidades de Manaus. Acta Amazonica. 2007; 37(2):303-308. https://dx.doi. org/10.1590/S0044-59672007000200019

13. Lourakis MIA. A Brief Description of the Levenberg-Marquardt Algorithm Implemented by levmar. Foundation of Research and Technology. 2005; 4(1):1-6. Disponível em http://users.ics.forth.gr/ lourakis/levmar/levmar.pdf

14. Le Cren ED. The Length-Weight Relationship and Seasonal Cycle in Gonad Weight and Condition in the Perch (Perca fluviatilis). Journal of Animal Ecology. 1951; 20(2):201-219. DOI: https://doi.org/10.2307/1540

15. Froese R, Pauly D. FishBase. World Wide Web electronic publication. (Accessed on December 2018). Available at: http://www.fishbase.de

16. Carlander K D. Handbook of freshwater fishery biology. Vol. 2. The Iowa State University Press. Ames. IA. 1997.

17. Froese R, Thorson JT, Reyes RB. A Bayesian approach for estimating length-weight relationships in fishes. Journal of Applied Ichthyology. 2014; 30(1):78-85. https://doi.org/10.1111/jai.12299

18. Lima EMM, Sousa KNS, Santos PRB, Ferreira LAR, Rodrigues AF, dos Santos Pantoja A. Relação peso-comprimento e fator de condição da pescada branca (Plagioscion squamosissimus, Heckel 1840) comercializada no município de Santarém, Pará, Brasil. Biota Amazônia. 2017; 7(2):44-48. Disponível em http://periodicos.unifap.br/index.php/ biota /article/view/3121/v7n2p44-48.pdf

19. Teixeira EC, Silva VEL, Fabré NN, Batista VS. Length-weight relationships for four stingray species from the tropical Atlantic Ocean. Journal of Applied Ichthyology. 2017; 33(3):594-596. https://doi.org/10.1111/jai.13255.

20. Santos JNS, Araújo FG, Silva DS. Length correction for early-juvenile Brazilian herring Sardinella janeiro (Eigenmann, 1894) after preservation in formalin, ethanol and freezing. Neotropical Ichthyology. 2009; 7(1):87-92. https:// dx.doi.org/10.1590/S1679-62252009000100011

21. Melo MT, Saturnino C, Santos JNS, Vasconcellos RM, Cruz-Filho AG, Araújo FG. Correction of the weight and length for juveniles Atherinella brasiliensis (Actinopterygii: Atherinopsidae) after fixation in formalin and preservation in ethanol. Zoologia. 2010; 27(6):892-896. https://dx.doi.org/10.1590/S1984-46702010000600009 